\title{
Coordinating the Overall Situation at China and Abroad
}

\author{
Zezheng $\mathrm{Xu}{ }^{1, \mathrm{a}}$, Zhiheng Gao ${ }^{1, \mathrm{~b}}$ and Zetong $\mathrm{Xu}^{2, \mathrm{c}}$ \\ 1. Coventry University, Coventry CV15FB, UK \\ 2. Qingdao Huanghai University, Shandong 266000, China \\ a Benjaminxzz@163.com, b gzh20001007@163.com, c2864609873@qq.com
}

\begin{abstract}
This report explains Coordinating the overall situation at China and abroad during 20 years. Considering the importance of domestic and foreign situations, China needs to adopt a global perspective, strengthen strategic thinking, grasp development opportunities, and respond to risks and challenges in the context of changes in the international situation. The report also put forward the requirements of enterprise innovation, through the courage to change, the courage to innovate and never fossilized, never stagnant efforts, not to be afraid of any risks, not to be confused by any interference of the firm will, promote the theoretical innovation, institutional innovation, cultural innovation.
\end{abstract}

Keywords: Coordinate; Business Development; Economic; China.

\section{Introduction}

In the current stage of development, opening up in all fields is necessary for development so that domestic resources and advantages in all aspects can be further developed. At the same time, we should also pay attention to the interaction of domestic and foreign markets. We should achieve joint development and win-win cooperation and pay attention to the respective advantages of the two different situations to achieve joint development. Finding a balance point between the two overall situations at home and abroad is an excellent test for our country and a tremendous challenge for our market. If the domestic market is fully opened, many foreign products will inevitably enter the Chinese market, thus affecting China's local industry to a certain extent. It also poses new challenges for the government, focusing on breaking down trade barriers and whether local protection policies promote economic development. In the future development process, the overall planning of domestic and foreign situations has become an indispensable melody of the development of The Times (Wang wei 2011). From another point of view, the overall consideration of domestic and foreign situations has become a necessary condition for sustained economic development and a necessary process of economic globalization. While promoting China's economic development, better-integrating development with the world economy has also become the overall domestic and overall foreign challenge. Concerning domestic and foreign information, we should always keep in mind that "reform is the absolute truth and development is the true way out (Xi Focus-Quotable Quotes: Xi Jinping on Ethnic Unity, Development-English n.d.)." In particular, when leading officials formulate policies, they should take measures in line with local conditions, avoid pulling the strings, and always bear in mind that "in the end, haste is too short." This means that the level of risk response and risk mitigation should be constantly improved, and sufficient mental preparation should be made to face the emergence of emergencies.

\section{Economic Development of China}

\subsection{Current Situation of Economic Development}

From the current situation, China has integrated into the development of the world economy. China has become the world's second-largest economy, and its GDP has maintained growth, especially during the epidemic period. China's economy has not experienced negative growth. This also shows that China's domestic economy and the changes in the global situation are in a relatively stable state. Finally, the proposal's core is reflected in three "new" aspects: new development stage, new 
development concept, and new development pattern. At home, we need to deepen reform, sustain economic development and lift the nation out of poverty as soon as possible. We need to realize the great rejuvenation of the Chinese nation based on the "two centenary goals." Externally, we must firmly safeguard national interests, uphold the bottom line that national sovereignty is inviolable, and strive for a favorable external environment for national economic development. This shows that China needs to participate more in global governance and protect its national interests fundamentally. In the 21 st century, peaceful development has become China's central theme. Under the new circumstances, China will stick to this rule. It also shows how China's struggle to balance domestic development with international friction has become an inescapable topic (The Rise of SelfEmployment in Rural China: Development or Distress?, n.d.). Of course, this does not mean giving up stability in the external world for national development, nor does it mean sacrificing domestic development for the sake of external stability. We need to balance the internal and external, which does not mean that we must sacrifice the interests of one party to develop. Win-win cooperation and harmonious development are the main melodies of this era. In this reform, the establishment of an open economic development system is the top priority of development. In international investment, we should encourage Chinese enterprises to go global and foreign enterprises to come in. It is essential to create a good business environment. In the development stage, it is inevitable to borrow the power of foreign capital to develop the economy, which is not a bad thing. From another perspective, China gradually began to attract foreign enterprises to invest in China, which is also a manifestation of the improvement of comprehensive national strength (Zhu, n.d.). As mentioned before, how to encourage enterprises to go out seems to be a complex problem. Many enterprises are afraid of going out, which leads to many new problems in the domestic economy. For example, without fresh blood for a long time, many enterprises start to satisfy themselves, which leads to slower and slower replacement of products and worse and worse quality of products. Therefore, it can be seen that foreign investment can promote the development of China's economy and promote the competition of local enterprises so that competitors will more guarantee the quality of products. On the other hand, foreign investment can add vitality to the domestic market and create a larger market for foreign investment. China is a country with a large population, which shows that China is a vast market. Therefore, it is a win-win approach for us to let foreign capital in and for our enterprises to go global, which is the central theme of this era.

\subsection{Mode of China Economic Development}

Xi Jinping once said that "we must be steadfast in our pursuit of development, forge ahead hand in hand in the course of unity and cooperation, and seek happiness for the people and development for the world." This also indicates that opening up will be a significant trend. It is not only China that needs to open its door to the rest of the world, but also other countries that need to have an open mind and resolve. The world should work together to make the pie of the global market bigger, make global development more solid, and invigorate global cooperation. Typical development and mutual assistance, and cooperation are the main melodies of this era. This is not only good for the global economy but also good for countries themselves. With the in-depth development of the global industrial chain and global supply chain, it is the general trend of The Times for countries to cooperate more closely. Countries are cooperating at the level of interests and building a community with a shared future. It is unacceptable for any country or individual to put the interests of all humanity above their own. We should follow the principle of openness in pursuing development, deepening cooperation among countries, pursuing cooperation rather than undermining each other, pursuing mutual benefit rather than exclusivity, and firmly opposing unilateralism, protectionism, and other detrimental actions to open development (Stoltenberg, 1984). President Xi pointed out that standing at a new historical starting point. China will only open wider to the outside world. China will open its arms to provide more market, investment, and growth opportunities for all countries to achieve joint development. China should set an example and deliver on its words, and help other countries as a significant country with a sense of responsibility. China should always maintain the new situation 
of domestic circulation as the main body, domestic and international double circulation, to promote economic development. China should put an end to the situation of internal circulation behind closed doors and adhere to the implementation of the strategy of expanding domestic demand and continue to increase the strength of opening to the outside world to form a new advantage of domestic and foreign development. From experience, we can conclude that reform and opening up are the cornerstones of economic development. Reform and opening up, as its name imply, are inseparable from reform and opening up. Their relationship is complementary and mutually promoting, the most prominent driving force for China's economic development. At the present stage, China has entered the Deepwater area of reform. The problem we now face is not simply how to get rid of poverty but how to solve the accumulated institutional obstacles and structural contradictions. We must strengthen the overall consideration of domestic and international situations and make changes in the external environment as a variable that cannot be ignored in domestic development. Not only to deepen the reform as the center to create conditions for opening up, but also to attract high-level industries to China to carry out in-depth reform to inject new vitality and add new blood to China's economy. Balancing the two overall situations is an inevitable requirement for China's connection and cooperation with the outside world. At present, China is the world's second-largest economy, trade in goods and foreign exchange reserves are the world's first, the increasingly frequent interaction with the international community in our country, global influence and participation of international affairs, internal and external work become integral, in this kind of situation, on the one hand, we should start according to our primary national conditions, We should formulate policies suitable for our development, unswervingly promote reform and choose a path suitable for ourselves and stick to it. On the other hand, we should closely link domestic development with external forms to realize benign interaction and win-win cooperation between China and other countries in the world.

\section{Oppoturnities \& Solutions of China's Development}

\subsection{Oppoturnities of China's Development}

Two overall situations as a whole to use good domestic market and foreign market, in order to realize the depth of the market, we must first fully tap the domestic market, China is a populous country of nearly 1.4 billion people, at the same time, the size of the market came second in the world, in the context of comprehensive poverty alleviation almost achieve, will further boost China's consumption ability, thus promoting consumption upgrading. Enterprises need to thoroughly investigate the market demand and, more importantly, how to produce better and more satisfying products for consumers so that consumers are willing to consume ("The Economic Impact of Special Economic Zones: Evidence from Chinese Municipalities," n.d.). Suppose only the government policy and the productivity of enterprise and innovation ability is not to ascend. In that case, consumers also will not pay for it, so not only will it promote the development of the economy, but economic development is not a particular group of tasks, but a whole society, to face all over the world. Secondly, we should actively explore the global market. The global market has a population of nearly 6 billion, which also shows that the global market is a big cake. This shows that we need to go deep into the market to develop diversified strategies. While developing traditional markets such as Europe and the United States, we should pay more attention to cooperation with countries along the Belt and Road and pay full attention to emerging markets in Asia, Africa, and Latin America to consolidate the hard-won market share. What is more, we should have more links between the domestic and foreign markets, improve the reform of the legal system, internationalization, standardization, and simplicity at home, and support Chinese enterprises to go global externally, guide the return of overseas consumption and promote the integration of the two markets at home and abroad.

\subsection{Solutions of China's Development}

Efficient use of domestic and foreign resources to achieve an efficient allocation of resources. Each country has its advantages and disadvantages. In the process of the layout of foreign markets, 
we should actively go out of the country to participate in the global trade to learn from each other and speed up their development. At the same time, going out for cooperation can also fully discover the problems facing China, such as fewer natural resources per capita, the low overall level of science and technology, environmental protection is still far from the international level, and core technology depends on foreign countries, and other problems are exposed. This is not a bad thing. It seems to be a spur to make full use of domestic resources and maximize production capacity while insisting on learning from foreign countries and introducing new technologies, not only to attract capital but, more importantly, to "attract wisdom." After Chinese enterprises go global, their capital, service, quality, and standard should exceed the international level. It is necessary to change simple trading into a more in-depth cooperative trade to enhance China's international competitiveness and further optimize the proportion of resources in the global scope.

Thoroughly study the characteristics of both domestic and international markets, and implement efficient convergence of rules. In the current stage, the frequent international rules vagaries and black swans, which can lead to the development of the multilateral trading system, encountered resistance, the world trade organization (WTO) has received the influence appears to influence the progress in regional economic cooperation is, in the developed economies are leading the trend of global economic development, China's enterprises to improve operation standard, the construction level and in environmental protection, Even beyond the international level, truly achieve Made in China, for the global economic development of welfare, occupy the commanding heights of the future international competition. In the course of development, we must always bear in mind the principle of fairness, justice, and openness and refrain from abusing power, excluding others, or even operating behind closed doors. Power must be kept in a cage to enhance China's voice in the international arena. Internally, China should adhere to the rule of law, internal and external overall planning, break the combination of establishment, fundamentally create a good investment environment, only have a sound, transparent business environment, is conducive to expanding opening-up, win-win cooperation, to form a balance between the domestic and foreign two overall situations. Adhere to the overall consideration of domestic and foreign situations, adhere to the mentality of openness and win-win cooperation, focus on solving the internal and external linkage of China's development, achieve complementary advantages, and avoid disadvantages with all countries in the world. We should firmly seize the opportunity of reform and adhere to the "four comprehensives" strategic plan of the CPC Central Committee (Interview: China's Development Led by CPC Awe-Inspiring for Other Countries, Says Palestinian Party Leader - Xinhua, n.d.). At the same time, we should improve the openness of China's coastal areas, with the coastal areas leading the inland and the south leading the north. Based on the domestic and global perspective, it constantly improves China's opening to the outside world. In the process of development, to keep in mind that the central party committee's deployment, adhere to "One Belt and One Road" for the handle, speed up the pace of opening up, to pursue health, the green economic development, if just for the sake of economic development despite all, would instead not do, can not to damage the environment in order to develop the economy, we must always bear in mind that green water castle peak is the precious deposits (Ferchen, 2020).

The 14th Five-Year Plan is a crucial period for China's economic development, from development to a period of profound readjustment. We should always adhere to the principle of mutual benefit, sharing resources and adhering to the bottom line of the environment, improving the existing bilateral and multilateral cooperation mechanisms, and promoting the development of interconnected cooperative relations. We will jointly build economic development cooperation corridors and special industrial development zones to promote policy, infrastructure, and resource connectivity in energy. Only in this way can we make economic development more dynamic by strengthening the in-depth cooperation in core fields such as science and technology at home and abroad and developing the external science and technology industry to form a development model with its characteristics. Support enterprises in western China to fully participate in the local government to help enterprises share the pressure and be good friends rather than commanders. Only in this way can China fully participate in the general trend of international economic development. 


\section{Summary}

To adhere to the overall consideration of both domestic and foreign situations, the key is to adhere to the principle of sustained development and sustained opening up, grasp the policy steadily, understand the policy thoroughly, create a good platform for enterprises, focus on solving the problems they encounter in the development, and create a new opening situation. We need to promote cross-border trade and cross-border investment from quantity to quality. We need to get rid of the problem of blindly pursuing quantity and ignoring quality in the past. Second, we need to develop new industries with standards, technology, quality, and service as the core to achieve the goal of transforming China from an economic powerhouse to an economic powerhouse. Implement the development strategy of optimal import and optimal export, pay attention to the development of hightech core enterprises and expand the scale of new export industries such as the equipment manufacturing industry, promote the development of transnational trade and improve China's position in international trade. We will implement a proactive import policy, open our doors to the global market, and promote the optimization of our industries and improve our per capita consumption level. Strengthen the spillover effect of foreign capital and promote global enterprises to invest in China to help domestic enterprises achieve real help. Domestically, we should constantly delegate power and hand over power to reduce government interference in enterprises. This will significantly improve the business environment and raise the new enthusiasm of foreign enterprises to invest in China. At the same time, it is necessary to improve the requirements of standardization and demand enterprises with higher standards to produce high-quality products. In this way, the domestic people can have better products to use and set up the change of Chinese manufacturing from inferior to high-quality in the international community to promote China's economic development. At the same time, the environmental supervision department should fully play its supervisory duties, no sacrifice at the expense of the environment to develop economy did not can earn money, the environmental damage to recover is brutal, not to damage the environment, to develop green, low pollution industry, keep in mind that the development requirements of the precious deposits as green castle peak (CSET Original Translation: China's 14th Five-Year Plan, 2021).

As a major responsible country, China should always adhere to the world's correct outlook on development and investment. While developing itself, China should actively shoulder its international responsibilities and obligations and provide more support and services to the international community. At the same time, we should improve the efficiency of external development, improve the situation where quantity exceeded quality in the past, and strictly control the quality of external development. We should expand the scale of foreign aid and provide more assistance to more developing countries and vulnerable countries. In the fields of medical treatment, science and technology, industry, and manufacturing, we should not only assist but also thoroughly learn from the development experience of developed countries to avoid detours.

\section{References}

[1] Wang Wei, PU Lijuan. The experience of correctly examining the international environment in the early stage of Reform and opening up [J]. Journal of party School of CPC Shanxi Province, 2011(2):3.

[2] Xi Focus-Quotable Quotes: Xi Jinping on ethnic unity, development-English-(n.d.). Retrieved November 8, 2021, from https://english.dbw.cn/system/2021/08/27/001437092.shtml.

[3] The rise of self-employment in rural china: Development or distress? (n.d.). Retrieved November 8, 2021, from https:// cn. bing. com/academic/ profile?id $=20 \mathrm{e} 1 \mathrm{~d} 647 \mathrm{e} 77 \mathrm{fb} 2 \mathrm{f0e} 28 \mathrm{dabeb} 85802 \mathrm{db} 7$ \&encoded $=$ $0 \& \mathrm{v}=$ paper_preview $\& \mathrm{cc}=\mathrm{cn}$.

[4] Zhu, X. (n.d.). Understanding China's growth: Past, present, and future - American Economic Association. Journal of Economic Perspectives, 26(4), 103-124. https://doi.org/10.1257/jep.26.4.103.

[5] Stoltenberg, C. D. (1984). China's special economic zones: Their development and prospects. Asian Survey, 24(6), 637-654. https://doi.org/10.2307/2644396. 
[6] The economic impact of Special Economic Zones: Evidence from Chinese municipalities. (n.d.). Journal of Development Economics, 101, 133-147. https://doi.org/10.1016/j.jdeveco.2012.10.009.

[7] Interview: China's development led by CPC awe-inspiring for other countries, says Palestinian party leader - Xinhua. (n.d.). English.News.Cn. Retrieved November 8, 2021, from http:// www. xinhuanet. com/ English/ 2021-07/07/c_1310047582.htm.

[8] Ferchen, M. (2020, January 8). How china is reshaping international development. Carnegie Endowment for International Peace. https:/carnegieendowment.org/2020/01/08/how-china-is-reshaping-international -development-pub-80703.

[9] CSET original translation: China's 14th five-year plan. (2021, May 12). Center for Security and Emerging Technology. https://cset.georgetown.edu/publication/china-14th-five-year-plan/. 